\title{
PENINGKATAN KUALITAS HIDUP MASYARAKAT MELALUI PEMETAAN KAPASITAS DAN KONDISI SOSIAL DI LINGKUNGAN DESA TANJUNG KECAMATAN CIPUNAGARA KABUPATEN SUBANG
}

\author{
Sri Rijati Wardani ${ }^{1}$, Mega Subekti², Tania Intan ${ }^{3}$ \\ ${ }^{1}$ Universitas Padjadjaran. Email: sri.rijati@unpad.ac.id \\ ${ }^{2}$ Universitas Padjadjaran. Email: mega.subekti@unpad.ac.id \\ ${ }^{3}$ Universitas Padjadjaran. Email: tania.intan@unpad.ac.id
}

\begin{abstract}
One of the classic problems that causes economic disparities is the uneven access to public education. Besides, the fundamental role of education is still not influential in efforts to improve people's living standard. Economic disparities also sharpen the gap between classes of society that has been formed, between the educated (well-educated) and less educated (non-educated). Assimilation was difficult to do in between these two groups. Institution that responsible to this issue is the Ministry of Education, because education is equipped to face the challenges of civilization in all fields. Universities also respond to this obligation by organizing Student Field Work Experience program (KKNM). These activities are designed in such way so that students can recognize and identify patterns that developed in the community, not just in terms of education, but also in other areas such as economics and livelihoods, social, cultural, and others.
\end{abstract}

Keywords: economic inequality, education, the pattern of community life

\begin{abstract}
ABSTRAK
Salah satu masalah klasik yang menjadi penyebab kesenjangan ekonomi adalah belum meratanya akses pendidikan kepada masyarakat. Selain itu peran fundamental pendidikan juga masih dirasa belum cukup berpengaruh dalam upaya meningkatkan taraf hidup rakyat. Kesenjangan ekonomi pun mempertajam jarak di antara kelas masyarakat yang sudah terbentuk, antara kaum terdidik (well-educated) dan kurang terdidik (non-educated). Pembauran pun sulit dilakukan di antara dua kelompok ini. Institusi yang paling bertanggung jawab dalam menangani isu ini adalah Kementrian Pendidikan, karena pendidikan merupakan bekal untuk menghadapi tantangan peradaban di semua bidang. Perguruan Tinggi pun merespon panggilan kewajiban ini dengan menyelenggarakan program Kuliah Kerja Nyata Mahasiswa (KKNM). Kegiatan ini dirancang dengan sedemikian rupa dengan tujuan agar mahasiswa dapat lebih mengenal dan mengidentifikasi pola-pola yang berkembang di masyarakat, bukan hanya segi pendidikan, namun juga bidang-bidang lain seperti ekonomi dan mata pencaharian, sosial, budaya, dan lain-lain.
\end{abstract}

Kata Kunci: kesenjangan ekonomi, pendidikan, pola kehidupan masyarakat 


\section{PENDAHULUAN}

Indonesia saat ini berada pada tahap lepas landas, yang salah satu indikatornya adalah keikutsertaannya dalam Masyarakat Ekonomi ASEAN (MEA)/ Asean Economic Community (AEC). Proyek ini telah lama dipersiapkan oleh komunitas regional ini untuk meningkatkan stabilitas perekonomian dan membentuk kawasan ekonomi antarnegara di wilayah Asia Tenggara yang kuat. Indikator lain adalah perkembangan situasi ekonomi kelas menengah yang kian pesat. Bank Dunia mencatat bahwa pertumbuhan kelas menengah di Indonesia berkembang dari 0\% pada tahun 1999 menjadi 6,5\% pada tahun 2011. Walaupun demikian, pendapatan per kapita masyarakat Indonesia masih dianggap timpang. Hal ini terbukti dari data yang menyatakan bahwa serapan pendapatan nasional oleh kalangan atas semakin meningkat. Di sisi lain, jumlah masyarakat miskin bertambah. Badan Pusat Statistik (BPS) memperkirakan bahwa jumlah penduduk miskin Indonesia per Maret 2015 lalu sebanyak 28,59 juta orang, setara dengan 11,22\% jumlah penduduk (BPS, 2015). Angka tersebut naik 850 ribu orang dibandingkan data September 2014 dengan 27,73 juta atau 10,96\% jumlah penduduk. Kenyataan ini menunjukkan bahwa kecenderungan masyarakat untuk lepas landas belum sepenuhnya berjalan baik.

Salah satu masalah klasik yang menjadi penyebab kesenjangan itu adalah belum meratanya akses pendidikan kepada masyarakat. Selain itu peran fundamental pendidikan juga masih dirasa belum cukup berpengaruh dalam upaya meningkatkan taraf hidup rakyat. Kesenjangan ekonomi yang meningkat pun (Festiana, 2015) mempertajam jarak di antara kelas masyarakat yang sudah terbentuk, antara kaum terdidik (well-educated) dan kurang terdidik (non-educated). Pembauran pun sulit dilakukan di antara dua kelompok ini.

Institusi yang paling bertanggung jawab dalam menangani isu ini adalah Kementrian Pendidikan, karena pendidikan merupakan bekal untuk menghadapi tantangan peradaban di semua bidang. Perguruan Tinggi pun merespon panggilan kewajiban ini dengan menyelenggarakan program Kuliah Kerja Nyata Mahasiswa (KKNM). Kegiatan ini dirancang dengan sedemikian rupa dengan tujuan agar mahasiswa dapat lebih mengenal dan mengidentifikasi pola-pola yang berkembang di masyarakat, bukan hanya segi pendidikan, namun juga bidang-bidang lain seperti ekonomi dan mata pencaharian, sosial, budaya, dan lain-lain.

Sekait dengan hal tersebut, dosen dapat berpartisipasi dengan menjadi Dosen Pembimbing Lapangan (DPL) sebagai bagian dari perwujudan Tri Dharma Perguruan Tinggi, khususnya Pengabdian Pada Masyarakat. Untuk tahun akademik 2016/2017, telah dibentuk tim PPM yang bertugas di Desa Tanjung Kecamatan Cipunagara Kabupaten Subang.

Letak Desa Tanjung cukup strategis karena desa ini berjarak relatif dekat dengan jalur protokol utama dan merupakan jalur protokol awal menuju desa-desa lain di Kecamatan Cipunagara, yang berbatasan langsung dengan Kabupaten Indramayu, dan Jawa Tengah. Oleh karena itu, masyarakat memiliki jangkauan yang cukup luas untuk mendapatkan sarana dan prasarana yang dibutuhkan. Secara tipologis, desa ini terdiri dari sejumlah wilayah persawahan dan ladang. Sedangkan tata guna lahan wilayah Desa 
Tanjung dipergunakan untuk pekarangan, pemukiman, perkantoran, pasar, dan kuburan. Luas total wilayah desa tersebut adalah 1.232 Ha dengan pola pemukiman mengikuti arah jalan raya dan jalan desa.

Menurut situs http://peta-jalan.com/kelurahandesa-tanjung-cipunagara-kabsubang/, Desa Tanjung berbatasan dengan wilayah-wilayah sebagai berikut:

1) Utara: Kecamatan Compreng

2) Barat: Desa Parigimulya

3) Selatan: Desa Manyingsal dan Desa Sidajaya

4) Timur: Kabupaten Indramayu

Desa Tanjung terdiri dari 5 dusun, yaitu: Dusun Tanjung, Dusun Sakurip, dusun Cipunagara, Dusun Sarimukti, dan Dusun Tanjungjaya. Jumlah warga desa ini sebanyak 10.129 jiwa. Sebagian besar warga telah tinggal di Desa Tanjung secara turun-temurun. Pendapatan perkapita desa ini rata-rata Rp. 3.205.094,00, yang menunjukkan bahwa tingkat kesejahteraan masyarakatnya menengah.

Secara umum Desa Tanjung memiliki potensi sumber daya alam yang cukup besar, berupa sawah dan ladang yang luas, sedangkan sumber air juga memiliki kondisi yang baik dengan adanya sungai besar yang dapat memenuhi kebutuhan harian masyarakat desa dan irigasi untuk persawahan. Di desa ini belum ada tempat wisata yang dapat menjadi sumber pendapatan bersama.

Desa Tanjung telah ada sejak tahun 1900-an. Nama Tanjung sendiri diperoleh dari nama sejenis bunga dengan nama yang sama. Pada saat itu, ada satu tanaman bunga uang tumbuh di jantung desa dan kemudian menjadi sumber ide bagi warga untuk memberi nama desa ini menjadi Desa Tanjung, siapapun yang datang dan tinggal di daerah ini akan merasa betah.

Kegiatan KKNM yang terintegrasi dengan PPM ini bertujuan mendapatkan ilmu dan pengalaman dari kehidupan sosial dari masyarakat setempat, dan juga mempelajari pemetaan sosial. Kegiatan dilaksanakan selama sekitar 1 bulan, dimulai dari tanggal 6 Januari - 4 Februari 2016.

Agar seluruh peserta mendapatkan hasil pembelajaran yang sama dan proporsional, maka dibentuk beberapa kelompok kerja yang masing-masing mempelajari aspek berbeda, di antaranya: aspek kewilayahan, aspek politik lokal, aspek ekonomi, aspek pendidikan, aspek kesehatan, aspek keagamaan, dan aspek budaya masyarakat.

Pemilihan lokasi kegiatan Pengabdian Pada Masyarakat ini didasari oleh kesepakatan Universitas Padjadjaran dengan pemerintah daerah setempat, sehingga telah terjalin kerja sama yang baik sebelumnya dengan aparat desa maupun warga sekitar. Perguruan Tinggi merupakan subsistem dalam pendidikan nasional, sehingga dengan menerapkan Tri Dharma PT, perguruan tinggi dapat berkiprah di dalam pembangunan nasional, terrmasuk dalam pembangunan desa (Sahlan, 2015). Kegiatan yang dilakukan diharapkan mampu memberikan solusi dan pemecahan bagi permasalahan yang ada di masyarakat. Hal ini merupakan bentuk kepedulian dan kontribusi institusi Perguruan Tinggi dalam pembangunan bangsa. 


\section{METODE PELAKSANAAN}

Metode yang digunakan dalam kegiatan Pengabdian Pada Masyarakat ini meliputi tiga tahapan, yaitu persiapan, pelaksanaan, serta evaluasi.

\section{Tahap persiapan}

Pada tahap ini dilakukan survey ke lokasi kegiatan, yaitu Desa Tanjung untuk mendapatkan gambaran yang obyektif dan faktual dari publik sekaligus mitra kegiatan Pengabdian Pada Masyarakat (PPM), untuk kemudian dibuat profil aktual dari wilayah desa tersebut sebagai bahan untuk penyusunan laporan kegiatan. Setelah itu dilakukan perencanaan kegiatan, yang meliputi jenis dan jadwal kegiatan, pemilihan dan penentuan media dan materi setiap kegiatan, serta penanggung jawab dan pelaksana setiap kegiatan. Rencana kegiatan ini disusun dalam bentuk modul kegiatan.

\section{Tahap pelaksanaan}

Pada tahap pelaksanaan, kegiatan dibedakan menjadi tiga jenis kegiatan, yaitu:

a. Koordinasi internal, yang dilakukan bersama oleh tim PPM dengan para mahasiswa yang sedang melaksanakan KKNM. Di dalam kegiatan ini, dilakukan pertemuan-pertemuan dan diskusi.

b. Kegiatan pengumpulan data yang dilakukan dalam kelompok-kelompok kerja yang membahas aspek berbeda.

c. Kegiatan pembuatan blog desa sebagai sarana publikasi mengenai Desa Tanjung. Luaran kegiatan ini disusun dan diterbitkan, sehingga nantinya bisa dimanfaatkan tidak hanya oleh mitra kegiatan, tetapi juga oleh publik yang lebih luas. Adapun identitas blog desa yang telah dibuat adalah sebagai berikut :

Nama : Desa Tanjung

Alamat : http://kknm.unpad.ac.id/tanjung

\section{Tahap evaluasi}

Tahapan terakhir meliputi evaluasi kegiatan yang telah dilakukan untuk mengukur sejauh mana keberhasilan yang telah dicapai sekaligus kekurangan yang masih terjadi, untuk kemudian dijadikan saran bagi penyelenggaraan kegiatan sejenis yang akan dilakukan kemudian. Setelah itu, hasil evaluasi akan disusun sebagai laporan kegiatan Pengabdian Pada Masyarakat (PPM).

\section{HASIL DAN PEMBAHASAN}

Semua kegiatan diselenggarakan sesuai dengan langkah-langkah yang sudah ditetapkan, yang meliputi persiapan, pelaksanaan, evaluasi, dan pelaporan. Jenis kegiatan yang dilakukan adalah upaya peningkatan kualitas hidup masyarakat melalui pemetaan kondisi sosial di Desa Tanjung Kecamatan Cipunagara Kabupaten Subang.

Kegiatan pemetaan kondisi sosial dilakukan pada awalnya untuk mendapatkan gambaran umum mengenai kondisi Desa Tanjung dengan informan/sasaran khalayak masyarakat desa tersebut. Seperti disampaikan sebelumnya, telah dibentuk kelompok kerja yang bertugas untuk mengumpulkan data mengenai aspek-aspek yang berbeda. 
Rijati, Peningkatan Kualitas Hidup....5

\section{Aspek Pemerintahan/ Politik}

Kegiatan dalam aspek ini dilakukan dengan cara observasi langsung dan wawancara dengan masyarakat guna mencari informasi tentang kondisi pemerintahan dan politik lokal di Desa Tanjung. Selain itu data juga diperoleh dari laman web Kabupaten Subang.

Menurut G.Suharto (2012), selama ini desa masih sering terabaikan dalam penyelenggaraan pemerintahan dan pembangunan. Di berbagai aspek kehidupan, khususnya sosial/ekonomi, desa dan masyarakatnya masih berada pada kondisi serba kekurangan, jauh tertinggal dibanding kondisi masyarakat di perkotaan. Tata kelola pemerintahan desa dipandang sangat menentukan kemajuan desa atau peningkatan kesejahteraan masyarakat desa, sehingga sudah semestinya pembenahan terhadap tata kelola pemerintahan desa menjadi fokus agenda bangsa Indonesia.

Data yang didapatkan tim PPM berkaitan dengan struktur pemerintahan, fungsi dan tugas masing-masing perangkat desa, program pemerintah, serta permasalahan dalam pemerintahan Desa Tanjung. Selain perangkat desa pada umumnya yang meliputi Kepala Desa, Sekretaris Desa, Kaur Umum, Kaur Keuangan, Kaur Kesra, Kaur Ekbang, Kaur Pemerintahan, serta Kepala Dusun, ada komponen penunjang pemerintahan yang mendukung, di antaranya Badan Permusyawaratan Desa (BPD), Lembaga Pemberdayaan Masyarakat (LPM), Pemberdayaan Kesejahteraan Keluarga (PKK), dan Karang Taruna (Karta).

Hal-hal lain yang dapat diungkapkan pula bahwa partisipasi politik masyarakat Desa Tanjung masih tergolong belum optimal, hanya 8 dari 10 anggota masyarakat menggunakan hak pilihnya dalam pemilihan kepala desa. Selain itu, PKK yang ada di Desa Tanjung tidak berfungsi sebagaimana mestinya.

Di sisi lain, dalam menjalankan aktifitas pemerintahan di Desa Tanjung, aparat desa mengadakan rapat rutin setiap hari Rabu, di antaranya untuk membahas perkembangan desa. Pembangunan lebih difokuskan pada sektor fisik, seperti pembangunan jalan dan rumah (renovasi/ bedah rumah). Selain itu terdapat beberapa program kerja desa yang menitikberatkan pada pemberdayaan masyarakat Desa Tanjung, agar lebih produktif dalam mengatasi permasalahan ekonomi khususnya.

\section{Aspek Ekonomi dan Mata Pencaharian}

Seperti pembahasan mengenai aspek pemerintahan dan politik, kegiatan untuk mendapatkan data mengenai aspek ekonomi dan mata pencaharian ini meliputi observasi langsung dan wawancara, serta pencarian melalui laman web Desa Tanjung (https://petadesa.klikdesa.com/desa/profil.php?id=3213150004).

Mayoritas masyarakat di desa ini bermata pencaharian sebagai buruh tani, seperti yang terungkap dari kondisi wilayahnya yang didominasi oleh sawah dan ladang. Selain menjadi petani, sebagian masyarakat juga menjadi karyawan perusahaan swasta yang ada di sekitar Desa Tanjung, di antaranya PT JAPFA yang berada di Dusun Sarimukti dan bergerak di bidang pembibitan ayam, serta PT LEONG. 
Angkatan kerja di Desa Tanjung terdiri dari 47,5\% penduduk dengan pendidikan rata-rata tamat SD. Kurangnya biaya disinyalir menjadi penyebab utama hambatan untuk melanjutkan pendidikan ke jenjang berikutnya.

Koperasi Unit Desa (KUD) Desa Tanjung tidak lagi beroperasi, seperti 90\% KUD lain di Kabupaten Subang. Namun demikian, di desa ini terdapat dua koperasi swadaya yang masih aktif, yang terletak di Dusun Cipunagara dan Dusun Sakurip. Kedua koperasi ini memiliki anggota yang aktif dan terus bertambah setiap tahunnya. Dalam hal lembaga keuangan, Desa Tanjung memiliki Badan Perkreditan Rakyat (BPR) dan satu bank milik pemerintah (BRI). BPR sangat penting keberadaannya terutama pada saat memasuki musim tanam. Masyarakat banyak menjaminkan SPOP dan BPKBnya. Selain BPR dan BRI, ada lembaga non-bank yaitu UPK, yang khususnya memberi pinjaman pada para petani.

Untuk sektor industri kecil dan menengah, industri makanan cukup banyak dilakukan oleh masyarakat Desa Tanjung, seperti pembuatan kerupuk, sale, dan tahutempe. Hasil industri ini ada yang dijual ke pasar dan dijual keliling. Sedangkan industri material bahan bangunan yang ada di desa ini rata-rata berupa penggalian pasir sungai.

Di Desa Tanjung hanya terdapat tiga rumah makan, masih dapat dikembangkan di kemudian hari, karena prospeknya cukup menjanjikan untuk daerah yang terletak di jalur protokol utama dan terus mengalami peningkatan ekonomi ini.

Di sektor usaha jasa pengangkutan, hanya ada satu armada angkutan desa. Ratarata masyarakat Desa Tanjung menggunakan kendaraan pribadi, namun angkutan umum masih sangat diperlukan keberadaannya, khususnya untuk para ibu dan anakanak yang belum memiliki SIM.

Mengenai usaha jasa dan perdagangan, Desa Tanjung memiliki satu pasar tradisional yang terletak di Dusun Cipunagara, yang sayurnya dipasok oleh para petani lokal desa ini dan Kabupaten Indramayu. Ada pula dua minimarket dan satu Warung Desa (Wardes), yang berfungsi sebagai supplier dari beberapa toko dan kios di seluruh desa.

Berkaitan dengan sektor usaha jasa gas dan BBM, Desa Tanjung memiliki SPBU. Selain itu, banyak terdapat penjual bahan bakar minyak eceran dan gas di sepanjang jalan desa. Hal ini disebabkan oleh jauhnya SPBU Pertamina terdekat, yang terletak di Pagaden (luar wilayah Kecamatan Cipunagara). Di sektor usaha jasa keterampilan, menjadi tukang batu dan tukang kayu merupakan profesi yang juga banyak dipilih masyarakat Desa Tanjung.

Dusun Tanjung Jaya merupakan dusun yang paling jauh dari kantor desa dan merupakan dusun yang masih belum optimal dalam pengelolaannya. Lahannya juga tidak cukup baik untuk ditanami. Oleh karena itu, perangkat desa memfokuskan pembangunan industri manufaktur di dusun tersebut agar dapat menyerap tenaga kerja secara maksimal.

\section{Aspek Pendidikan}

Menurut Mohammad Ali (2009:58) aspek yang penting diperhatikan untuk memberdayakan manusia menuju pembangunan adalah pendidikan, karena dengan 
pendidikan kita tidak hanya mempunyai bekal pengetahuan tetapi juga memiliki kemampuan untuk berpartisipasi aktif dalam setiap kegiatan pembangunan masyarakat.

Dengan adanya pendidikan, masyarakat bisa berpikir kreatif dan mampu mengikuti perubahan seperti penggunaan inovasi baru, penerapan teknologi, dan pola pikir yang brorientasi pada pembangunan. Masyarakat yang tidak mampu berubah untuk mengikuti perkembangan zaman akan semakin tertinggal. Dalam keadaan seperti ini, struktur ekonomi masyarakat pedesaan akan tetap berada dalam ambang kemiskinan. Selain itu, Gregorius Sahdan (2005) mengungkapkan mengenai sejumlah variabel yang dapat digunakan dalam mengidentifikasi masalah dalam kemiskinan, salah satu dimensinya adalah pendidikan yaitu rendahnya pendidikan merupakan salah satu penyebab kemiskinan.

Kegiatan mengumpulkan data mengenai aspek pendidikan dilakukan dengan cara observasi langsung, wawancara dengan kepala dusun dari tiap dusun yang ada di Desa Tanjung dan masyarakat terkait dengan informasi keseluruhan yang ada, sarana prasarana, serta tingkat pendidikan rata-rata dari masyarakat. Selain itu, data juga didapatkan dari aparat Desa Tanjung, dari aparat Kecamatan Cipunagara, dan laman web Kabupaten Subang.

Di Desa Tanjung, pendidikan sudah cukup baik, dengan fasilitas dan lembaga pendidikan yang cukup memadai, ada 6 PAUD, 5 SD/sederajat, 2 SMP/sederajat, dan 1 SMKN.

Namun demikian, kenyataan menunjukkan bahwa sebagian besar masyarakat desa ini baru mengenyam pendidikan terakhir SD, walaupun sekolah dengan tingkat yang lebih tinggi telah disediakan pemerintah. Bahkan ada juga masyarakat yang sudah menempuh pendidikan tinggi (D3 dan S1).

Dalam kegiatan KKNM-PKM Integratif, mahasiswa melakukan kegiatan observasi pada lima lembaga pendidikan, untuk mendapatkan data mengenai lenbaga pendidikan serta memberikan bantuan sederhana berupa materi dan bahan ajar pada lembagalembaga tersebut.

Pada umumnya, dapat ditarik simpulan bahwa motivasi belajar siswa sudah cukup baik namun tidak diiringi oleh kesadaran orang tua untuk membiayai pendidikan ke tingkat yang lebih tinggi. Faktor ekonomi juga seringkali menjadi alasan.

\section{Aspek Kesehatan}

Kegiatan pengumpulan data mengenai pembangunan aspek kesehatan dilakukan dengan metode observasi langsung dan wawancara dengan masyarakat Desa Tanjung, berkaitan dengan kegiatan keseharian, pengelolaan sampah, kondisi air dan lain-lain. Informasi juga didapatkan dengan melalui wawancara aparat desa serta laman web Kabupaten Subang, yang dikaji lebih lanjut guna mengetahui kondisi kesehatan, permasalahan kesehatan, fasilitas atau lembaga kesehatan, serta sarana dan prasarana kesehatan.

Untuk menunjang kesehatan warganya, Desa Tanjung memiliki bangunan Puskesmas dan delapan Posyandu. Puskesmas sendiri terletak di Dusun Cipunagara, ada dua dokter, yaitu dokter umum dan dokter gigi. Selain itu, ada juga apotek, yang dikelola 
apoteker, namun para profesional ini bukan warga asli Desa Tanjung. Empat bidan ditugaskan di desa ini, namun peralatan kesehatan secara keseluruhan dapat dikatakan tidak lengkap dan masih sangat sederhana.

Posyandu yang terdapat di Desa Tanjung melayani imunisasi, penanganan ibu hamil serta pelayanan kesehatan lainnya. Luasnya wilayah Desa Tanjung dan kurangnya jumlah tenaga kesehatan yang tersedia, membuat program-program Posyandu tidak selalu dapat dilaksanakan dengan baik secara rutin setiap hari. Hal ini kemudian diatasi dengan diagendakannya kegiatan Posyandu yang dilakukan sebulan sekali pada hari berbeda di tiap Posyandu yang ada. Permasalahan lain yang tampak dari ketidakseimbangan antara luas daerah dengan jumlah tenaga kesehatan adalah ketidakefektifan pelayanan kesehatan. Kurangnya pelatihan pada para kader PKK dan Posyandu juga menyebabkan tidak terpenuhinya fungsi sarana kesehatan yaitu memberikan penyuluhan fungsi KMS, nutrisi sehat, ASI eksklusif, dan kesehatan perempuan pada umumnya.

\section{Aspek Kehidupan Beragama}

Kegiatan untuk mendapatkan data tentang kehidupan beragama dilakukan dengan observasi langsung dengan masyarakat, dan wawancara berkaitan dengan kegiatan keagamaan, perayaan keagamaan, dan data mengenai pemeluk agama yang ada di Desa Tanjung.

Dari data yang terkumpul, diketahui bahwa masyarakat Desa Tanjung terdiri dari 99\% penganut agama Islam dan 0,1\% sisanya terdiri dari pemeluk agama Kristen dan Kepercayaan Kepada Tuhan YME. Dengan demikian, jelas mengapa di desa ini terdapat 8 mesjid dan 19 mushola sebagai sarana peribadatan. Adapun penunjang kegiatan keagamaan lainnya berada di sekolah-sekolah yang dibangun dengan berbasis keagamaan, seperti Raudhatul Athfal (PAUD), Madrasah Ibtidaiyah (SD), dan Madrasah Tsanawiyah (SMP). Selain itu, Desa Tanjung juga memiliki Dewan Kemakmuran mesjid yang menunjang kegiatan keagamaan dengan jadwal yang intensif seperti kegiatan yasin mingguan, kegiatan pengajian ibu-ibu mingguan, peringatan Maulid Nabi Muhammad SAW, pelaksanaan shalat Ied, peringatan Nudzulul Qur'an dan Lailatul Qadar, peringatan Isra Mi'raj, serta peringatan 1 Muharram. Padatnya kegiatan keagamaan ini, tidak diiringi dengan sikap antusias kaum muda untuk mengikutinya. Hal ini terbukti dari pengamatan mahasiswa KKNM yang menyimpulkan bahwa kegiatan keagamaan di Desa Tanjung lebih banyak diikuti oleh orang-orang yang telah lanjut usia.

\section{Aspek Budaya}

Kegiatan mengumpulkan data mengenai aspek ini dilakukan sedikit berbeda dengan aspek-aspek lainnya. Wawancara dilakukan langsung dengan masyarakat Desa Tanjung terutama pada para sesepuh, untuk mendapatkan gambaran luas mengenai kebudayaan, kebiasaan, upacara adat, dan perayaan budaya lainnya.

Dalam lingkungan masyarakat petani Desa Tanjung, budaya nenek moyang masih sangat teguh dijunjung. Mereka menghormati dan mengistimewakan tumbuhan khususnya padi. Mereka meyakini bahwa selain sebagai bahan pokok pangan, padi ini 
merupakan hasil dari aktifitas para dewa dan leluhur yang suci. Salah satu di antaranya adalah Dewi Sri sebagai dewa yang memberikan kemakmuran bagi masyarakat. Oleh karena itu, warga Desa Tanjung masih melaksanakan upacara Hajat Bumi ketika akan menghadapi musim tanam selepas musim kemarau serta saat menghadapi musim panen. Upacara ini dianggap sebagai ungkapan rasa syukur pada leluhur untuk segala nikmat dan kemakmuran yang telah mereka dapatkan. Hajat Bumi diadakan satu tahun sekali, dengan rangkaian acara yang terdiri dari Ngaruwat Bumi dan Mapag Sri.

Pada acara Ngaruwat Bumi, para sesepuh dan aparat desa serta masyarakat pada umumnya ikut memeriahkan upacara tersebut, yang terdiri dari acara arak-arakan, ritual babaritan, dan pagelaran wayang golek. Saat arak-arakan, masyarakat yang berada di rumah menyiramkan air pada peserta arak-arakan. Hal ini bermakna sebagai permintaan kepada Tuhan YME untuk mendatangkan hujan. Selanjutnya pertunjukan wayang golek dilaksanakan mulai dari pagi hingga malam hari. Tema utamanya adalah mengenai Sari Pohaci (Dewi Sri) dengan latar belakang agama Budha namun digunakan dalam konteks keIslaman untuk berdakwah.

Rangkaian lain yang juga menarik adalah Ritual Babaritan yang digelar di perempatan jalan yang merupakan persinggungan empat arah jalan yang biasa dilalui penduduk di Desa Tanjung. Semua kepala keluarga mengirimkan wakilnya, biasanya ibu rumah tangga, untuk membawa makanan yang terdiri dari nasi dan lauk pauk untuk disertakan dalam ritual ini. Kegiatan berlangsung pada sore hari menjelang magrib, dengan dipimpin seorang sesepuh. Sesepuh ini akan memimpin pembacaan doa yang berisi ayat suci Al Quran dan pembakaran kemenyan. Pada puncak doa, sesepuh mengajak masyarakat untuk berdoa bersama agar sawah dan ladang mereka diberkati.

Selain hal-hal tersebut di atas, aspek budaya setempat masih sangat dihormati di Desa Tanjung, seperti misalnya Upacara Mapag Sri dan Sisingaan. Walaupun sudah tergolong masyarakat modern, warga Desa Tanjung masih mempertahankan budaya tradisional secara turun-temurun.

\section{SIMPULAN}

Secara umum, tanggapan masyarakat terhadap program KKNM-PKM Integratif ini pun baik, sehingga seluruh rangkaian kegiatan terlaksana dengan baik pula. Kegiatan dimulai dari tahap persiapan dan orientasi wilayah untuk pencarian data dan informasi terkait kondisi desa.

Peran Perguruan Tinggi memang harus lebih ditingkatkan dalam upaya pemberdayaan masyarakat pada umumnya, agar nilai maslahat dari sebuah pendidikan dapat dinikmati oleh semua kalangan.

\section{DAFTAR RUJUKAN}

Festiani, S. (2015). Angka Kesenjangan Ekonomi 2015 Diperkirakan Naik. Retrived Juli 12, 2016 from Republika: http://republika.co.id/berita/ekonomi/makro/15/04/26/nndjnt-angkakesenjangan-ekonomi-2015-diprediksikan-naik 
Suharto, D. G. (2015). Penyelenggaraan Pemerintahan Desa Dalam Perspektif Desentralisasi Administratif Dan Desentralisasi Politik. Jurnal Bina Praja: Journal of Home Affairs Governance, 4(3), 153-160.

Tanjung2016. (2016). Profil Umum. Retrived Juli 18, 2016 from kknm unpad tanjung 2016: https://kknm.unpad.ac.id/tanjung/2016/01/16/profil-umum/

Statistik, Badan Pusat. (2015). Persentase Penduduk Miskin Maret 2015 Mencapai 11, 22 Persen. Retrived Juli 19, 2016 from Badan Pusat Statatistik. https://www.bps.go.id/pressrelease/2015/09/15/1158/persentase-pendudukmiskin-maret-2015-mencapai-11-22-persen.html

Mohammad, A. (2009). Pendidikan untuk pembangunan nasional. Bandung: PT Imperial Bhakti Utama.

Sahdan, G. (2005). Menanggulangi kemiskinan desa. Retrived Juli 16, 2016 from Jurnal Ekonomi Rakyat: http://www.ekonomirakyat.org/edisi_22artikel_6.html

Sahlan, A. (2015). Pemerintah Akui Butuh Dukungan Mahasiswa dan Kampus. Retrived Juli 16, 2016 from teropongsenayan: http://www.teropongsenayan.com/8890pemerintah-akui-butuh-dukungan-mahasiswa-dan-kampus 